Communications in Physics, Vol. 27, No. 2 (2017), pp. 121-130

DOI:10.15625/0868-3166/27/2/9811

\title{
FABRICATION OF ORGANOLEAD IODIDE PEROVSKITE SOLAR CELLS WITH NIOBIUM-DOPED TITANIUM DIOXIDE AS COMPACT LAYER
}

\author{
NGUYEN TRAN THUAT ${ }^{1, \dagger}{ }^{\dagger}$ BUI BAO THOA ${ }^{2}$, NGUYEN BAO TRAN ${ }^{2}$, \\ NGUYEN MINH TU ${ }^{1}$, NGUYEN NGOC MINH ${ }^{1}$, HOANG NGOC LAM HUONG ${ }^{1}$, \\ PHAM THU TRANG ${ }^{3}$, PHAN VU THI VAN ${ }^{3}$, TRUONG THANH TU ${ }^{1}$ \\ AND DANG TUAN LINH ${ }^{1}$ \\ ${ }^{1}$ Nano and Energy Center, VNU University of Science \\ ${ }^{2}$ Department of Advanced Materials Science and Nanotechnology, \\ University of Science and Technology of Hanoi \\ ${ }^{3}$ Faculty of Engineering Physics and Nanotechnology, \\ VNU University of Engineering and Technology \\ ${ }^{\dagger} E$-mail: thuatnt@ vnu.edu.vn
}

Received 17 May 2017

Accepted for publication 16 June 2017

Published 30 June 2017

\begin{abstract}
Organometal halide perovskite materials have shown high potential as light absorbers for photovoltaic applications. In this work, perovskite planar solar cells were fabricated on corning substrates with the structure as follows: the first layer made of tantalum-doped tin oxide as transparent contact material, followed by sputtering niobium-doped titanium oxide as the compact electron transport layer; covered with perovskite $\mathrm{CH}_{3} \mathrm{NH}_{3} \mathrm{PbI}_{3}$ as the light harvester by combination between spin-coating and dipping methods; CuSCN was evaporated as the hole transport layer; the final thin Al/Ag electrodes were deposited. This configuration is shortly described as Al/TTO/NTO/CH $\mathrm{H}_{3} \mathrm{NH}_{3} \mathrm{PbI}_{3} / \mathrm{CuSCN} / \mathrm{Ag}$. Such heterojunctions are expected to be suitable for the development of efficient hybrid solar cells. The fabricated cells were measured under the air mass 1.5 illumination condition showed the rectification effect and exhibited a power conversion efficiency of $0.007 \%$ with a open circuit voltage of $53.2 \mathrm{mV}$ a short circuit current of $0.36 \mathrm{~mA} / \mathrm{cm}^{2}$, and a form factor of $37 \%$. The power conversion efficiency will be further optimized in near future.
\end{abstract}

Keywords: perovskite, $\mathrm{CH}_{3} \mathrm{NH}_{3} \mathrm{PbI}_{3}$, solar cells, NTO, TTO, CuSCN.

Classification numbers: 73.50.-h; 85.30.-z; 88.40.H-, 88.40.J-. 


\section{INTRODUCTION}

The world population is estimated to increase by more than one billion people within 15 years, thus the energy requirement will be clearly increased to accommodate this rapid expansion of the population and strong economic growth. Sunlight is one of the renewable energy sources that can globally contribute enough to this needed. Therefore, in order to use this source of energy in an effective way, A. E. Becquerel was one of the first inventors who discovered the ability of generating electric current from light in aqueous solution [1]. Then as it is generally known, silicon-based solar cells have been developing [2], followed by the inorganic-based solar cells [3]. However, these solar cells involve high manufacturing cost to reach the demand of increasing their performance. Hence, this is where perovskite solar cells enter [4]; as for the first time in photovoltaic (PV) history it is possible to produce high-efficiency cells at low costs, apparent ease of fabrication from earth-abundant, readily available raw materials [5]. The organometal halide $\mathrm{AMX}_{3}\left(\mathrm{~A}=\right.$ organic cation such as $\mathrm{CH}_{3} \mathrm{NH}_{3}^{+}, \mathrm{CH}\left(\mathrm{NH}_{2}\right)_{2}^{+}, \mathrm{CH}_{3} \mathrm{CH}_{2} \mathrm{NH}_{3}^{+} \ldots ; M=$ metal cation such as $\mathrm{Pb}, \mathrm{Sn} ; X=$ halogen anions such as $\mathrm{I}, \mathrm{Cl}, \mathrm{Br}$ ) were developed and attributed strong light absorption, bipolar transporting abilities, balanced electron and hole diffusion lengths, low charge recombination and easy fabrication process. By looking to the history, Mitzi et al. was one of the first inventors who discovered the optoelectronic applications of organic-inorganic hybrid perovskite for effective transistors and electroluminescent devices in the 1990s [6-9]. However the used of these layer for photovoltaic devices have not been attractive since 2009 when Miyasaka $e t$ al. [10] reported the first attempt of perovskite as a sensitizer in their dye sensitized solar cells with a power conversion efficiency (PCE) of $4 \%$. By replacing the electrolyte by a solid hole transport medium, the PCE of perovskite-based solar cells (PSC) could be hugely improved [11]. Over a period of 10 years, PCE of perovskite solar cells (PSCs) has sharply increased to $20.1 \%$ [12] showing an inviting vista of commercialization $[13,14]$.

A typical configuration of perovskite solar cells is described as followings: the perovskite material layer is aligned between a hole-transporting layer (HTL) which also acts as electronblocking layer (EBL) and an electron-transporting layer (ETL) which also acts as hole-blocking layer (HBL), along with the additional electrode and transparent conducting oxide (TCO) substrate [15]. Two main device architectures are mesoscopic structure [16] which use mesoporous metal oxide materials and planar heterojunction structure without any mesoporous layer [17]. Perovskite materials absorb the incident light, generates electrons and holes, which are then injected to the ETL and HTL and finally moved to the electrodes. The planar structure of PSCs has no scaffold layer in the active layer, hence can avoid high temperature from the fabricating process of mesoporous metal oxides. This provides more flexibility for device optimization, multijunction construction, investigation of the underlying device physics and nonlinear optics [18-24]. Hence the planar structure turns out to be very attractive for basic research purposes [25].

In this paper, we present a framework fabrication of planar PSCs with the stack $\mathrm{Al} / \mathrm{TTO} / \mathrm{NTO} / \mathrm{CH}_{3} \mathrm{NH}_{3} \mathrm{PbI}_{3} / \mathrm{CuSCN} / \mathrm{Ag}$. The cells were completely built from precursor materials to devices. Each layer had been studied for the compatible material structure and optimal properties for applications in solar cells. This work followed these prior works by commencing the fabrication with the combination of each single layer into functioning PSCs, and specially by using tantalum-doped tin oxide (TTO) [26] and respectively niobium-doped titanium oxide (NTO) [27], for the electrode and compact layer respectively 


\section{EXPERIMENTAL}

\section{II.1. Fabrication of TTO and NTO}

TTO and NTO thin films were deposited on glass substrate by co-sputtering methods. The sputtering conditions for these two first layers are listed on Table 1. These conditions had been obtained through our prior optimization works for applications in thin film solar cells. In this paper, the NTO thin film could be used as the compact layer for conducting electron, acting as the hole-blocking layer. The niobium-doped effect is for increasing the electron concentration of the compact layer.

Table 1. TTO and NTO sputtering conditions.

\begin{tabular}{lcc}
\hline \hline Deposition parameters & TTO layer & NTO layer \\
\hline \hline Target & $\mathrm{SnO}_{2}$ and $\mathrm{Ta}$ & $3 \% \mathrm{Nb}$-doped $\mathrm{TiO}_{2}$ \\
\hline $\mathrm{RF}$ power & $60 \mathrm{~W}$ at $\mathrm{SnO}_{2}$ target & $90 \mathrm{~W}$ \\
\hline DC power & $45 \mathrm{~W}$ at Ta target & $\mathrm{N} / \mathrm{A}$ \\
\hline Time & $1 \mathrm{~h}$ for $\mathrm{RF}$, two $2-$ min durations for DC & $10 \mathrm{~min}$ \\
\hline Base pressure & $<5 \times 10^{-6} \mathrm{Torr}$ & $<5 \times 10^{-6} \mathrm{Torr}$ \\
\hline Sputter pressure & $7.5 \times 10^{-3} \mathrm{Torr}$ & $7.5 \times 10^{-3} \mathrm{Torr}$ \\
\hline Temperature & $300{ }^{\circ} \mathrm{C}$ & Room temperature \\
\hline Ar flow rate & $20 \mathrm{sccm}$ & $20 \mathrm{sccm}$ \\
\hline $\mathrm{O}_{2}$ flow rate & $0.5 \mathrm{sccm}$ & $0 \mathrm{sccm}$ \\
\hline Target-substrate distance & $10 \mathrm{~cm}$ & $10 \mathrm{~cm}$ \\
\hline
\end{tabular}

\section{II.2. Fabrication of perovskite thin films}

For thin films $\mathrm{CH}_{3} \mathrm{NH}_{3} \mathrm{PbI}_{3}$ fabrication, $\mathrm{PbI}_{2}, \mathrm{CH}_{3} \mathrm{NH}_{3} \mathrm{I}$ and $\left(\mathrm{PbI}_{2}+\mathrm{CH}_{3} \mathrm{NH}_{3} \mathrm{I}\right)$ solutions were prepared separately for distinct fabrication methods below. At first, $0.922 \mathrm{~g}$ lead (II) iodide $\left(\mathrm{PbI}_{2}\right)$ (purchased from Acros) was dissolved in $2 \mathrm{~mL} \mathrm{~N}, \mathrm{~N}$-Dimethylformamide (DMF) solvent to form a $1 \mathrm{M}$ concentration solution and stirred at $70{ }^{\circ} \mathrm{C}$ for $30 \mathrm{~min}$. $0.05 \mathrm{M} \mathrm{CH}_{3} \mathrm{NH}_{3} \mathrm{I}$ solution was synthesized by dissolving $0.318 \mathrm{~g} \mathrm{CH}_{3} \mathrm{NH}_{3} \mathrm{I}$ in $40 \mathrm{~mL}$ isopropanol $\left(\mathrm{C}_{3} \mathrm{H}_{8} \mathrm{O}\right)$ (IPA) at $70{ }^{\circ} \mathrm{C}$ for $15-20$ min. $1 \mathrm{M}$ of $\mathrm{PbI}_{2}+\mathrm{CH}_{3} \mathrm{NH}_{3} \mathrm{I}$ mixture solution in DMF was synthesized by dissolving $\mathrm{CH}_{3} \mathrm{NH}_{3} \mathrm{I}$ powder with $\mathrm{PbI}_{2}$ powder in DMF under nitrogen atmosphere at $70{ }^{\circ} \mathrm{C}$ for 10 to 15 minutes. Perovskite thin films were prepared by 2 different methods: The $1^{s t}$ method, commercial $\mathrm{CH}_{3} \mathrm{NH}_{3}+\mathrm{PbI}_{3}$ powder in DMF solvent was spin coated at $4000 \mathrm{rpm}$ for $90 \mathrm{~s}$. The $2^{\text {nd }}$ method, a two-step spin-coating process was performed under nitrogen atmosphere. $\mathrm{PbI}_{2}(1 \mathrm{M})$ in $\mathrm{DMF}$ solution was spin-coated at $2000 \mathrm{rpm}$ for $90 \mathrm{~s}$. The obtained sample was rinsed in isopropyl alcohol (IPA). Next step, the sample was dipped into the $\mathrm{CH}_{3} \mathrm{NH}_{3} \mathrm{I}(0.05 \mathrm{M})$ solution twice in 3 min, between 2 times dipping, the sample was annealed at $100{ }^{\circ} \mathrm{C}$ for $15 \mathrm{~min}$. The as spun films 
were annealed at $100{ }^{\circ} \mathrm{C}$ for $30 \mathrm{~min}$ in the case of one-step method and for $15 \mathrm{~min}$ in the case of two-step method, to evaporate the solvent and better surface coverage.

\section{II.3. Fabrication of CuSCN layer}

Unlike other reports on using CuSCN as effective inorganic hole transport medium for PCS [28], in this study, CuSCN thin films were deposited by thermal evaporation method. It was reported that $\mathrm{CuSCN}$ was thermally decomposed under atmospheric condition containing oxygen [29]. It was surprisingly found during our study that CuSCN could be deposited also by thermal evaporation with a quite sophisticated current adjustment procedure. The obtained $\mathrm{CuSCN}$ exhibited a quite high $p$-type conduction property

\section{II.4. Fabrication of PSCs}

In a simple perovskite solar cell, the active layer $\left(\mathrm{CH}_{3} \mathrm{NH}_{3} \mathrm{PbI}_{3}\right)$ is sandwiched between the hole and electron transport layer (HTL and ETL). The layer structure of the present photovoltaic cells is denoted as $\mathrm{Al} / \mathrm{TTO} / \mathrm{NTO} / \mathrm{CH}_{3} \mathrm{NH}_{3} \mathrm{PbI}_{3} / \mathrm{CuSCN} / \mathrm{Ag}$, as shown in the schematic illustration of Fig. 1a. At first, corning substrates were cut into $15 \times 15 \mathrm{~nm}$ square pieces and rinsed in acetone, methanol and water, on an ultrasonic vibration plate for 10 minutes, respectively. Next, substrates were dipped in piranha solution $\left(\mathrm{H}_{2} \mathrm{O}_{2}: \mathrm{H}_{2} \mathrm{SO}_{4}=1: 3\right)$ for 1 hour. Finally, wafers were vibrated in ethanol and DI water again and dried in a flow of nitrogen.

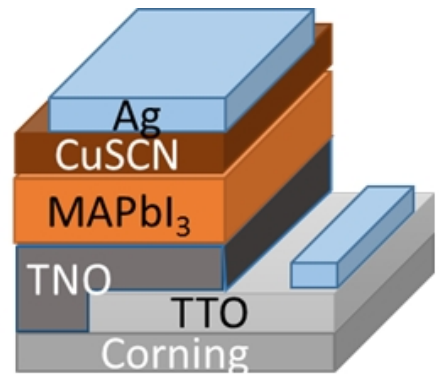

(a)

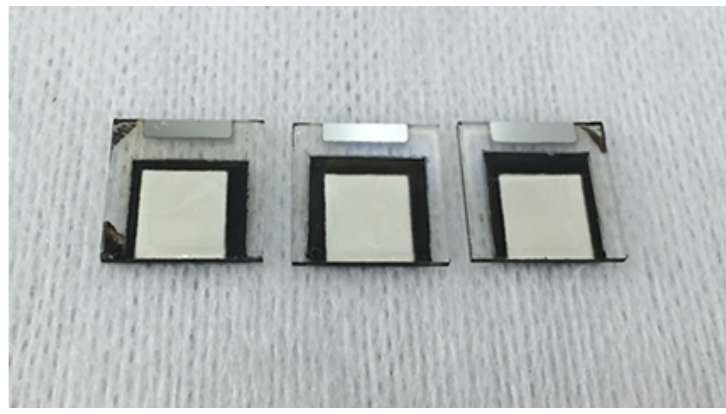

(b)

Fig. 1. Perovskite solar cell structure using in this work (a) and photograph of complete PSCs (b).

Then TTO layer was deposited by co-sputtering method, with a $\mathrm{SnO}$ and a Ta target, on cleaned corning substrates. The form of TTO layer was defined by using the first shadow mask. Then the NTO layer was deposited also by sputtering method, with a $\mathrm{TiO}_{2}$ doped $3 \% \mathrm{Nb}$ target. The form of NTO layer was defined by using the second shadow mask. After that, TTO and NTO coated substrates were transferred into a nitrogen-filled glovebox for perovskite spin-coating step The form of perovskite layers was defined by manually removing unwanted areas prior to the annealing step.

Next, the samples were quickly placed in the thermal evaporation or sputtering chamber for the deposition of CuSCN and electrodes layer at room temperature. CuSCN and Ag layers were deposited in 60 min by thermal evaporation method with the third shadow mask. Al was deposited by sputtering method with the fourth shadow mask. Complete perovskite solar cells fabricated by our method are showed in Fig. $1 b$. 


\section{II.5. Characterization}

The structural characterization of achieved perovskite layers was performed by x-ray diffraction (XRD) spectroscopy on a Bruker D8 Advance diffractometer using $\mathrm{Cu} \mathrm{K} \alpha$ radiation. The morphology was observed by scanning electron microscopy (SEM) on an FEI Nova NanoSEM 450 system. The J-V characteristics of the photovoltaic cells were measured under standard illumination using a solar simulator with an intensity $P_{L I G H T}=100 \mathrm{~mW} / \mathrm{cm}^{2}$. Air mass 1.5 one sun illumination condition was calibrated by using a commercial calibration solar cell. The JV characteristics were investigated by a Keithley 2602. The instruments are connected to a dedicated computer and are controlled by Keithley LabTracer Software. The sampling interval was $20 \mathrm{~s}$. The solar cells were illuminated through the side of TTO layer, and the illuminated area was 0.32 $\mathrm{cm}^{2}$ for all samples. From the obtained JV characteristics, the maximum output power $\mathrm{P}_{M A X}$, the open voltage $\left(V_{O C}\right)$ and the short circuit current density $\left(J_{S C}\right)$ are deduced. Based on these values, one can calculate the fill factor (FF) as following

$$
F F=\frac{P_{M A X}}{J_{S C} \cdot V_{O C}}
$$

and the PCE as following

$$
P C E=\frac{P_{M A X}}{P_{L I G H T}}=\frac{J_{S C} \cdot V_{O C} \cdot F F}{P_{L I G H T}}
$$

\section{RESULTS AND DISCUSSION}

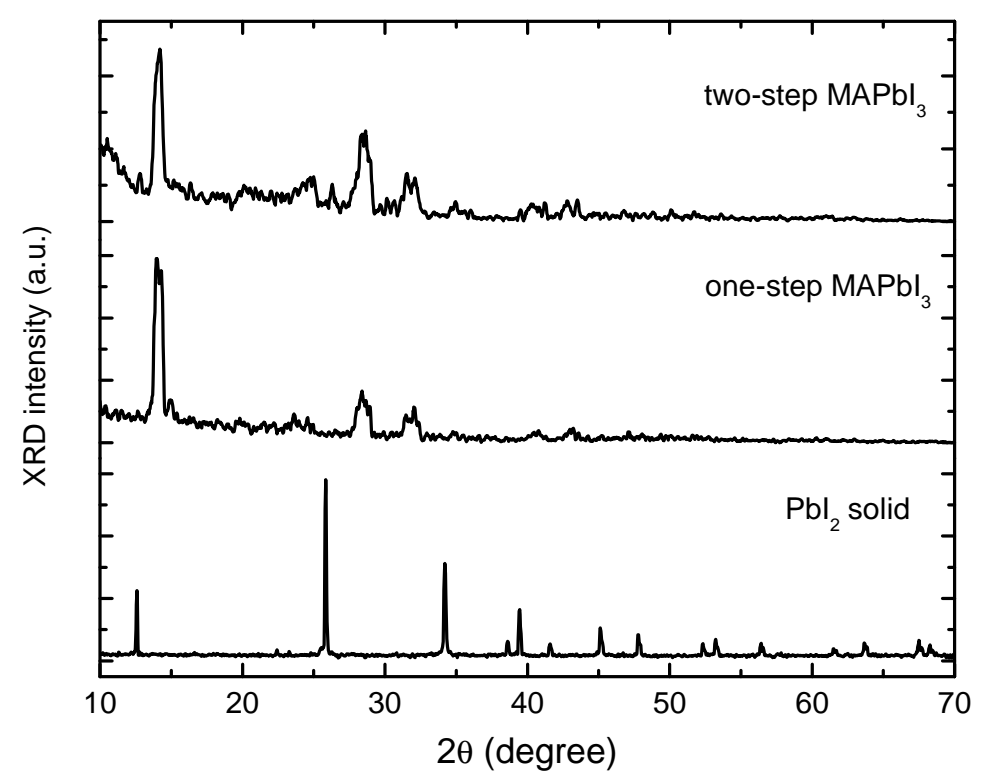

Fig. 2. XRD patterns of synthesized $\mathrm{MAPbI}_{3}$ layers and commercial $\mathrm{PbI}_{2}$ powder.

Figure 2 shows $\mathrm{XRD}$ patterns of $\mathrm{MAPbI}_{3}$ layers via one-step and two-step method on glass substrates, and in comparison with the XRD pattern of $\mathrm{PbI}_{2}$ powders. The XRD pattern of $\mathrm{PbI}_{2}$ 
corresponds to the hexagonal crystalline structure, exhibiting strong $2 \theta$ peaks at $12.58^{\circ}, 25.58^{\circ}$, and $34.21^{\circ}$. XRD patterns of $\mathrm{CH}_{3} \mathrm{NH}_{3} \mathrm{PbI}_{3}$ layers correspond to the tetragonal (or "pseudocubic") crystalline structure of this organometal halide compound. The peaks calculated for the perovskite $\mathrm{CH}_{3} \mathrm{NH}_{3} \mathrm{PbI}_{3}$ is tetragonal I4/mcm phase with lattice constants of $a=8.8 \AA, c=12.68 \AA$, indicating a good agreement with the simulation. When considering the strong peaks of $\mathrm{PbI}_{2}$ at angle of $27^{\circ}$, there was no observable residual peak in the perovskite XRD patterns thus showing that the reaction for forming perovskites on substrates surface was complete. One observes also that the XRD peaks of $\mathrm{CH}_{3} \mathrm{NH}_{3} \mathrm{PbI}_{3}$ layers are more broaden than those of $\mathrm{PbI}_{2}$. This may be a direct result of nanosized perovskite crystallites.

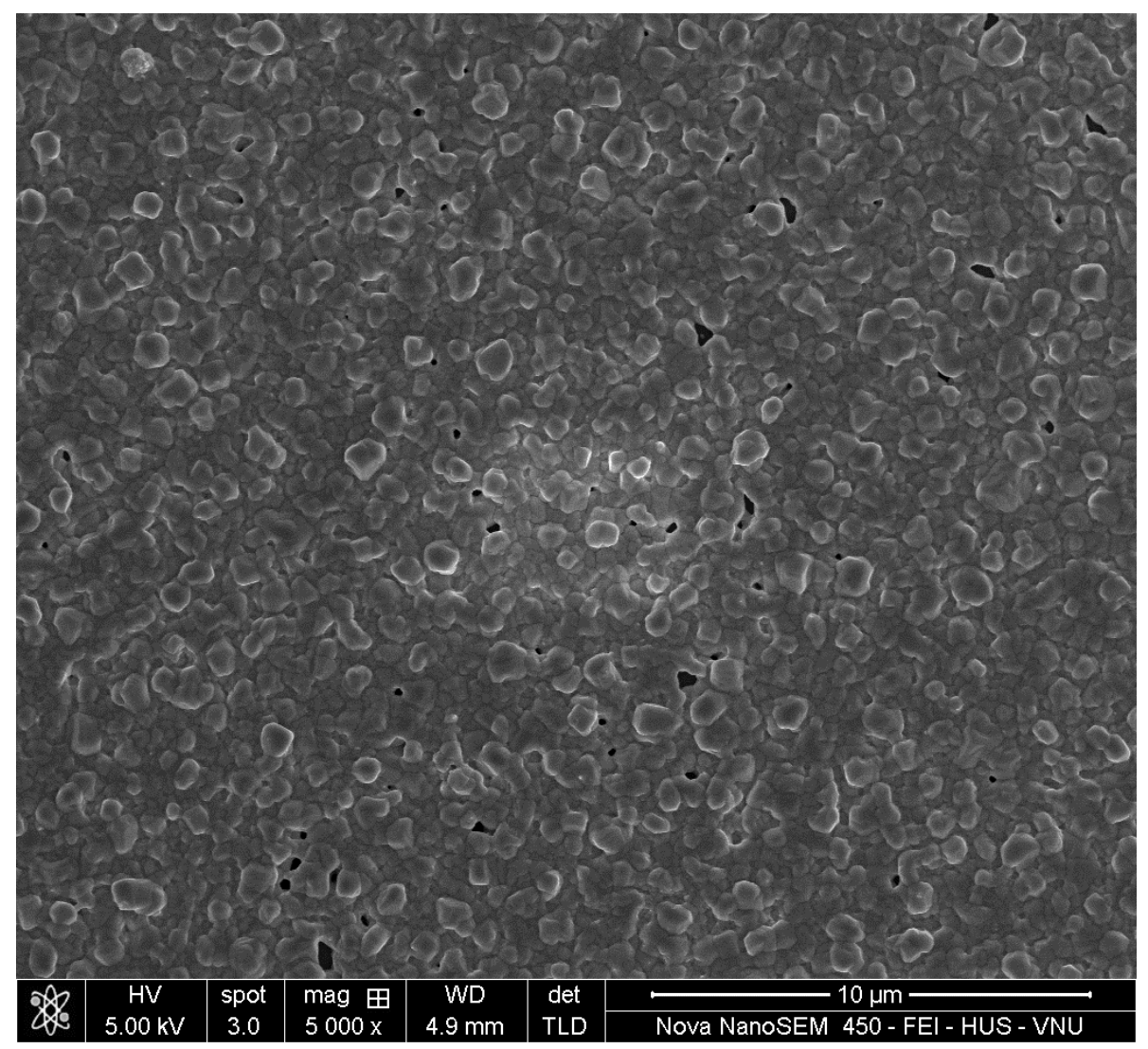

Fig. 3. SEM micrographs of $\mathrm{CH}_{3} \mathrm{NH}_{3} \mathrm{PbI}_{3}$ fabricated via two-step method.

The morphology of two-step $\mathrm{CH}_{3} \mathrm{NH}_{3} \mathrm{PbI}_{3}$ layer is showed in Fig. 3. As can be seen on the micrograph, the morphology of the active layers appears different sized blocks. These blocks can be considered as single crystals thus there is a quite large size distribution of $\mathrm{CH}_{3} \mathrm{NH}_{3} \mathrm{PbI}_{3}$ nanocrystals. This agrees with the broadening peaks observed on XRD patterns in Fig. 2. Additionally, some small pinholes are seen on the surface of the $\mathrm{CH}_{3} \mathrm{NH}_{3} \mathrm{PbI}_{3}$ layer. This problem can affect the PCE of solar cells if this $\mathrm{CH}_{3} \mathrm{NH}_{3} \mathrm{PbI}_{3}$ layer is used as the absorber, thus more careful spin and dip coating procedure should be applied. 
A typical band diagram structure used for perovskite solar cells in this study are shown in Fig. 4. The electron affinity values were taken from the literature [30] NTO and CuSCN, respectively, play the role of ETL and HTL, respectively. As shown in the diagram, the alignment of the energy position of the NTO conduction band, at $-4.0 \mathrm{eV}$, is closely under the conduction band of $\mathrm{CH}_{3} \mathrm{NH}_{3} \mathrm{PbI}_{3}$, at $-3.9 \mathrm{eV}$, while the valence band of $\mathrm{CuSCN}$, at $-5.3 \mathrm{eV}$, is slightly above the valence band of $\mathrm{CH}_{3} \mathrm{NH}_{3} \mathrm{PbI}_{3}$, at $-5.4 \mathrm{eV}$. This ensures an efficient charge separation for solar cells fabricated by this stack of layers.

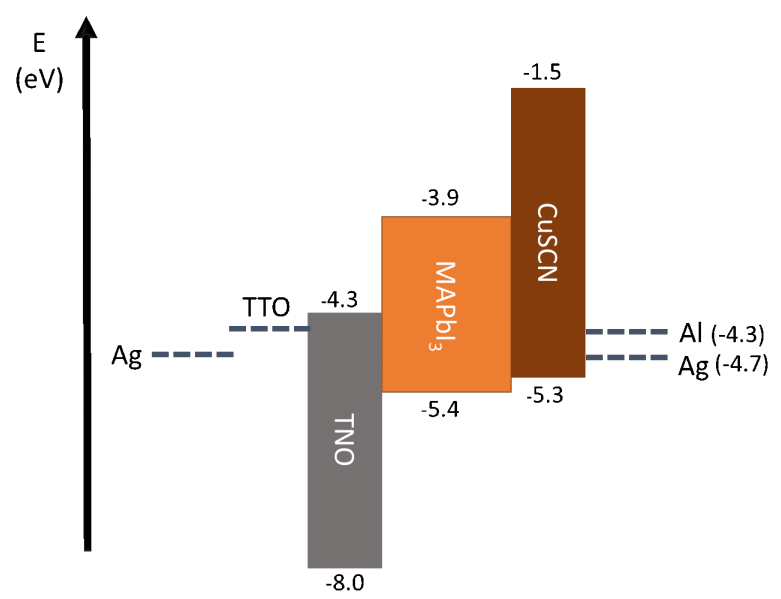

Fig. 4. Band diagram of PSCs in this work, blocks denote bandgaps and lines are for Fermi levels of metals.

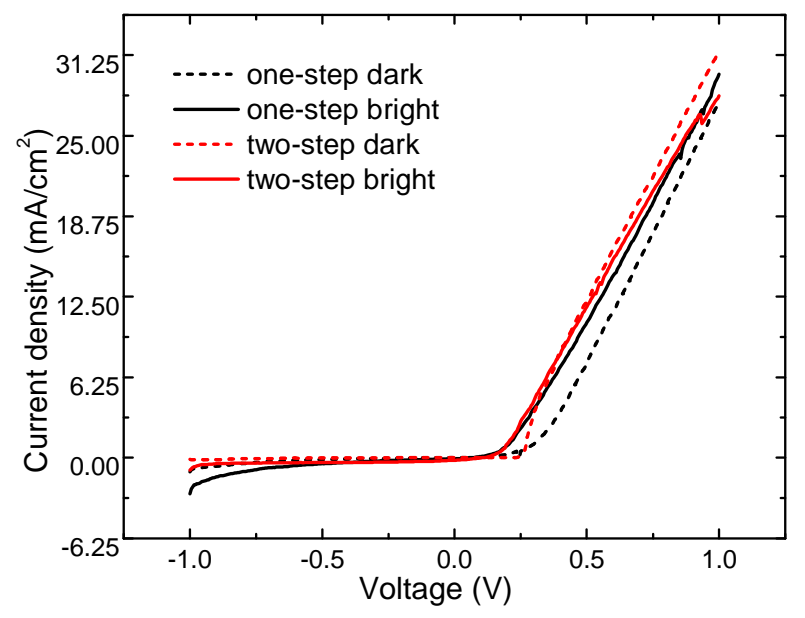

Fig. 5. Dark and bright JV characteristics of perovskite solar cells with good rectification effect. The perovskite active layer was deposited via one-step and two-step method.

Figure 5 shows dark and bright JV characteristics of PCS for which the active layer was fabricated via one-step and two-step method. In the interval of scanning voltage, from $-1 \mathrm{~V}$ to 
$-1 \mathrm{~V}$, these cells exhibited quite good rectification effect. The reversed current is closed to zero for a voltage range from $-1 \mathrm{~V}$ to about $50 \mathrm{mV}$. When the bias voltage is higher than $50 \mathrm{mV}$, the forward current density increases linearly. This is a characteristic of a diode with a high series resistance. It can be seen easily that, when samples were illuminated, no photocurrent is obtained. This could be explained by two possibilities: (i) incident light was totally reflected from the samples, or (ii) the defect density was too high that any photon absorption induced free carriers were trapped and recombined. For the configuration of PSCs fabricated in this paper, the second phenomenon may be the main reason of having no photocurrent, thus further improvement is needed.

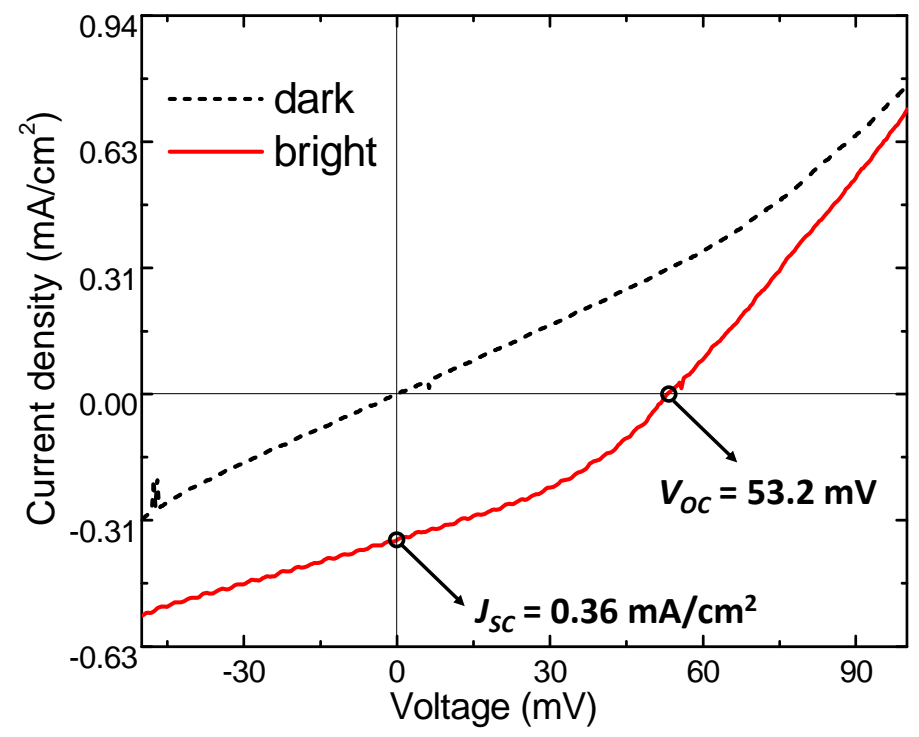

Fig. 6. Dark and bright JV characteristics of a working perovskite solar cell.

In order to obtain cells with photocurrent, many optimization was taken into consideration such as: (i) the shadow mask alignment between depositions, (ii) the homogeneity of the active perovskite layer for avoiding pinholes, (iii) the thickness of the blocking layer, (iv) the reduction of time intervals between depositions, (v) the optimization of CuSCN deposition. Fig. 6 shows the dark and bright JV characteristics of a PCS with photovoltaic effect. The $J_{S C}$ is $0.36 \mathrm{~mA} / \mathrm{cm}^{2}$ and the $V_{O C}$ is $53.2 \mathrm{mV}$. The FF is $37 \%$ and the PCE is $0.007 \%$, which is quite low in comparison to other configuration of PSCs in the literature. Due to the experimental conditions several hypotheses have been proposed. It is thought that problems come from poor charge transport intra- and interlayer, from high interface and bulk recombination trap density. The JV curve appears rather high series and low shunt resistivity. The high series resistance could be attributed to the high resistance of TTO layer. In this study, since the TTO layer is quite thin, the sheet resistivity was measured, to be around $300 \Omega / \square$, regarding to about less than $10 \Omega / \square$ used for other PSCs in the literature. This resistance increases the series resistance of the device and leads to a decrease in the photocurrent density. The low shunt resistance could be attributed to the fact that: (i) layers were not well aligned, leading to overlap between electrode layers, and (ii) many pinholes in the perovskite layer as can be seen from the SEM micrographs. 
According to a recent study of carrier separation and transport in PSCs [31], the operation mechanism was due to $p-n$ junction at the interface of $\mathrm{TiO}_{2}$ /perovskite and minority-carrier diffusion/drift rather than due to the $p-i-n$ structure or an excitonic cell. As can be seen on Figure 4, there appeared a high difference in the work function of energy level alignment at the interface of $\mathrm{CH}_{3} \mathrm{NH}_{3} \mathrm{PbI}_{3}$ and NTO layer. This gives rise to a built-in electric filed perpendicular to the device surface, which facilitates the drift motion of minority carrier and their extraction at the electrode contacts. The open circuit voltage of PSCs depends on the built-in electric filed. In this work, the NTO was doped $3 \%$ with $\mathrm{Nb}$. This doping level could affect the built-in voltage at the interface $\mathrm{CH}_{3} \mathrm{NH}_{3} \mathrm{PbI}_{3} / \mathrm{NTO}$ thus varying the doping level should be taken into consideration. Another reason that can affect the built-in voltage is the HTL. In this study, this layer was CuSCN deposited by thermal evaporation method. Even though a good $p$-type conduction and high band gap layer was obtained, there may be a mismatch of the band gap alignment in comparison with the literature shown in Fig. 4. As a result, the built-in voltage drop across the cell may not be as high as expected, and hence the power conversion efficiency could be significantly low.

\section{CONCLUSION}

In summary, organohalide perovskite based photovoltaic devices were fabricated via solution spin coating. These solar cells used TTO as the transparent conductive layer and NTO as the compact blocking layer. The hole-transporting layer was CuSCN deposited by a careful current adjustment thermal evaporation procedure. The photovoltaic properties of the cells were investigated under AM1.5 one sun illumination condition. PSCs with photovoltaic functionality were obtained with an open circuit voltage of $53.2 \mathrm{mV}$, a short circuit current density of $0.36 \mathrm{~mA} / \mathrm{cm}^{2}$, a FF of $37 \%$ and a PCE of $0.007 \%$. These results highlight that the hybrid perovskite solar cells could be fabricated with the configuration $\mathrm{Al} / \mathrm{TTO} / \mathrm{NTO} / \mathrm{CH}_{3} \mathrm{NH}_{3} \mathrm{PbI}_{3} / \mathrm{CuSCN} / \mathrm{Ag}$ by our fabrication framework. Further optimization will be developed in near future for increasing the PCE and for fully understanding the working mechanism of these PSCs.

\section{ACKNOWLEDGEMENTS}

The authors greatly acknowledge the financial support of the National Foundation for Science and Technology Development - NAFOSTED under Project No. 103.02-2014.81 "Synthesis of organic-inorganic perovskite materials for application of absorber layers in hybrid heterojunction solar cells". The authors would like to thank for research equipment from the project named "Strengthening research and training capacity in fields of Nanoscience and Technology, and Application in Medical, Pharmaceutical, Food, Biology, Environmental protection and Climate Change adaptation in the direction of sustainable development" of the Vietnam National University Hanoi.

\section{REFERENCES}

[1] H. Spanggaard and F. C. Krebs, Sol. Energy Mater. Sol. Cells 83 (2004) 125.

[2] D. M. Chapin, C. S. Fuller and G. L. Pearson, J. Appl. Phys. 25 (1954) 676.

[3] M. Grätzel, J. Photochem. Photobiol. C Photochem. Rev. 4 (2003) 145.

[4] H.S. Jung and N. Park, Small 11 (2015) 10.

[5] M. A. Green, K. Emery, Y. Hishikawa, W. Warta and E. D. Dunlop, Prog. Photovoltaics Res. Appl. 24 (2016) 905.

[6] D. Weber, Zeitschrift Für Naturforsch. B 33 (1978) 862. 
[7] D. Weber, Zeitschrift Für Naturforsch. B 33 (1978) 1443.

[8] D. B. Mitzi, C. A. Feild, W. T. A. Harrison and A. M. Guloy, Nature 369 (1994) 467.

[9] D. B. Mitzi, C. A. Feild, Z. Schlesinger and R. B. Laibowitz, J. Solid State Chem. 114 (1995) 159.

[10] A. Kojima, K. Teshima, Y. Shirai and T. Miyasaka, J. Am. Chem. Soc. 131 (2009) 6050.

[11] H.-S. Kim, C.-R. Lee, J.-H. Im, K.-B. Lee, T. Moehl, A. Marchioro, S.-J. Moon, R. Humphry-Baker, J.-H. Yum, J. E. Moser, M. Grätzel and N.-G. Park, Sci. Rep. 2 (2012) 591.

[12] W. S. Yang, J. H. Noh, N. J. Jeon, Y. C. Kim, S. Ryu, J. Seo and S. Il Seok, Science 348 (2015) 1234.

[13] D. Bi, B. Xu, P. Gao, L. Sun, M. Grätzel and A. Hagfeldt, Nano Energy 23 (2016) 138.

[14] M. Habibi, F. Zabihi, M.R. Ahmadian-Yazdi and M. Eslamian, Renew. Sustain. Energy Rev. 62 (2016) 1012.

[15] N. Park, J. Phys. Chem. Lett. 4 (2013) 2423.

[16] M. M. Lee, J. Teuscher, T. Miyasaka, T. N. Murakami and H. J. Snaith, Science 338 (2012) 643.

[17] J. M. Ball, M. M. Lee, A. Hey and H. J. Snaith, Energy Environ. Sci. 6 (2013) 1739.

[18] H. Kim, I. Mora-Sero, V. Gonzalez-Pedro, F. Fabregat-Santiago, E. J. Juarez-Perez, N. Park and J. Bisquert, Nat. Commun. 4 (2013) 2242.

[19] F. Brivio, A. B. Walker and A. Walsh, APL Mater. 1 (2013) 42111.

[20] J. Even, L. Pedesseau, J. Jancu and C. Katan, J. Phys. Chem. Lett. 4 (2013) 2999.

[21] P. Docampo, F. C. Hanusch, N. Giesbrecht, P. Angloher, A. Ivanova and T. Bein, APL Mater. 2 (2014) 81508.

[22] J. Kim, S. Lee, J.H. Lee, K. Hong, J. Phys. Chem. Lett. 5 (2014) 1312.

[23] C. Eames, J. M. Frost, P. R. F. Barnes, B. C. O. Regan, A. Walsh and M. S. Islam, Nat. Commun. 6 (2015) 7497.

[24] T. Van Phan Vu, M. T. Nguyen, D. T. T. Nguyen, T. D. Vu, D. L. Nguyen, N. M. An, M. H. Nguyen, C. D. Sai, V. D. Bui, C. H. Hoang, T. T. Truong, N. D. Lai and T. Nguyen-Tran, J. Electron. Mater. 46 (2017) 3622.

[25] M. Liu, M. B. Johnston, H. J. Snaith, Nature 501 (2013) 395.

[26] N. M. Nguyen, M. Q. Luu, M.H. Nguyen, D. T. Nguyen, V. D. Bui, T. T. Truong, V. T. Pham and T. Nguyen-Tran, J. Electron. Mater. 46 (2017) 3667.

[27] N. M. Hieu, N. T. Lan, N. B. Loc, N. T. T. Hang, N. T. Tien, P. V Thanh, L. M. Quynh, N. H. Luong and N. L. H. Hoang, J. Electron. Mater. 46 (2017) 3726.

[28] P. Qin, S. Tanaka, S. Ito, N. Tetreault, K. Manabe, H. Nishino, M. K. Nazeeruddin, M. Gratzel, Nat. Commun. 5 (2014) 3834.

[29] B. Ptaszyñski, E. Skiba and J. Krystek, Thermochim. Acta 319 (1998) 75.

[30] E. Science and W. Seattle, Energy Environ. Sci. 8 (2015) 1160.

[31] C.-S. Jiang, M. Yang, Y. Zhou, B. To, S. U. Nanayakkara, J. M. Luther, W. Zhou, J. J. Berry, J. van de Lagemaat, N. P. Padture, K. Zhu and M. M. Al-Jassim, Nat. Commun. 6 (2015) 8397. 